\title{
REPRODUCTIVE ASPECTS OF BANANA PRAWN (Fenneropenaeus merguiensis) FOR RECOMMENDATIONS OF THE SOUTH SORONG MPA ZONE
}

\author{
Arya K. Dhani*a,c, Ehdra Beta Marsana ${ }^{\mathrm{c}}$, Duranta D. Kembaren ${ }^{\mathrm{b}}$, Mansura ${ }^{\mathrm{c}}$, Chris Rotinsulu $^{\mathrm{c}}$ \\ ${ }^{a}$ Directorate of Marine and Fisheries Program, WWF-Indonesia, Bali, Indonesia \\ ${ }^{\mathrm{b}}$ Research Institue for Marine Fisheries, Ministry of Marine Affairs and Fisheries, Cibinong, Indonesia \\ ${ }^{\mathrm{c}}$ USAID SEA Project, South Jakarta, Indonesia \\ *Corresponding author : aryakdhani2018@outlook.com
}

\begin{abstract}
Reproduction aspects of banana prawn were important in determining of the fisheries management. These results can indicate the condition of fisheries that are or will be managed. Banana prawn was one of the main commodities in South Sorong fisheries. This study aims to estimate some of the reproductive aspects of Fenneropenaeus merguiensis as part of a management measure to determining the zone to be a no-take zone area in the prospective area of South Sorong MPAs. The data analyzed were from data collecting from January to December 2018 in three sampling sites in South Sorong, among others Inanwatan, Bakoi, and Konda with the results of 5,009 carapace length samples, 4,589 including sex observation and 3,621 including banana prawn GMS observations. Data analysis performed by analyzing the distribution of carapace length frequency, sex ratio, length-weight relationship, length at first maturity (Lm50), and length at first captured (Lc50). The results of this analysis showed that the ratio between male and female gender was not balanced, with male gender to be less with a ratio of $0.4: 1.4$ overall in NTZ 2 and 3. Comparison of Lc and Lm in NTZ 2 and NTZ 3 were respectively Lc $<$ Lm and Lc $>$ Lm. More fishing pressure will have implications to reduce the average size of banana prawn caught. Overall, NTZ 3 had relatively more stable conditions compared to NTZ 2.
\end{abstract}

Keywords : NTZ, ratio, Lm, Lc.

\section{INTRODUCTION}

The South Sorong Regency is known to have fisheries potential, especially banana prawn, which is an export commodity. The USAID SEA Project in 2017 recorded an estimated banana prawn fishery production reaching more than 6 tons/month which, if averaged, could reach $19.79 \mathrm{~kg} /$ trip/fisherman [1]. The existence of this potential is supported by the existence of "Essential Ecosystems" of mangroves covering an area of 76,171 Ha, consisting of 72,904 $\mathrm{Ha}$ of primary mangrove forests and 3,266 $\mathrm{Ha}$ of secondary mangrove forests [1]. The mangrove area is used as a spawning area, nursery ground, feeding area by marine biota with high economic value, one of which is the Fenneropenaeus merguiensis banana prawn with the scientific name that previously had the name Penaeus merguiensis [2].

Utilization of banana prawn in the district of South Sorong is mainly carried out using three-layer gill nets (trammel net) around the sandy loam waters with an area that is overgrown by mangrove forests with a depth of about 5-10 meters with a fishing fleet under 10 gross tonnage. Prawn fishing activities are carried out throughout the year by using a three-layer gill net (trammel net) in shallow water. According to [3], the distribution of Indonesian waters of prawn includes shallow marine waters concentrated along the west coast of Sumatra to the coast of Papua.

The nursery habitat favored by the penaeid prawn group is an estuary region with good or freshwater mass input or heavily influenced by the tidal process with flowing substrates consisting of mud and sand and has a lot of litter [4]. The habitat conditions are following the characteristics of South Sorong waters and are the basis for Indigenous Peoples initiating the formation of zoningbased Marine Protected Area in the South Sorong Regency.

However, fishing activities in the designed conservation area can pose threats, such as loss of stock due to overfishing in 
areas that should no-take zones. This threat is now slowly being experienced by fishing communities such as the loss of fishing grounds. The number of catches has decreased and there is a struggle for fishing ground. The condition is exacerbated by the lack of data and information in designing the potential of the core zone in the marine protected area. Thus, it is feared that the population in the wild will decrease and the protected water conservation areas that are initiated do not have a positive impact on supporting sustainable fisheries.

This has led WWF-Indonesia, SEA Project, and Ministry of Marine Affairs and Fisheries to research the aspects of banana prawn reproduction to support the effectiveness of the no-take zone (NTZ) in the South Sorong Waters Conservation Area. Thus, the decreasing population concern can be balanced with the quality of effective management.

\section{MATERIAL AND METHOD}

\section{Study Sites}

Data collection was conducted from January to December 2018 from the banana prawn landing center in South Sorong Regency which included 3 locations namely Inanwatan, Bakoi, and Konda (Figure 1).

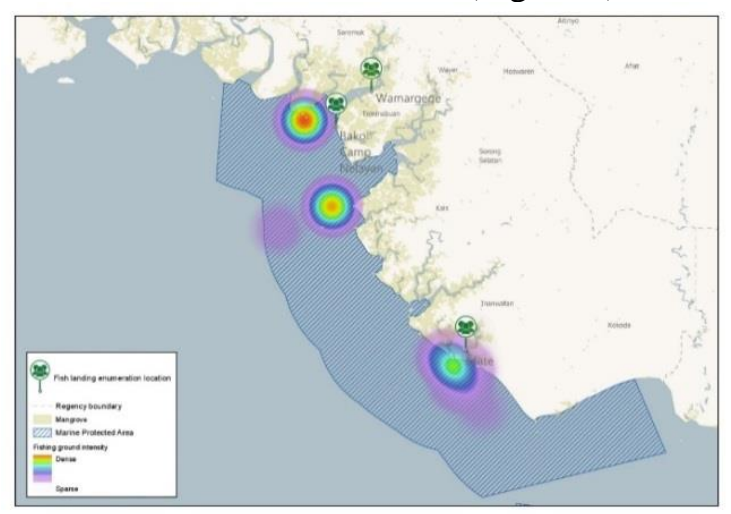

Figure 1. Banana Prawn Data Collection Location in South Sorong Regency

\section{Data Collection}

Prawn recorded are the catch of fishermen around the prospective marine protected area (MPA) of South Sorong from the catch with trammel net. Sampling was done by purposive sampling method to get the proportion of prawn size desired, representing all the characteristics of the fleet, fishing gear, and fishing ground. Data taken included carapace length, individual gross weight, gonad maturity stage, sex, and fishing ground.

Carapace length measurements were carried out using calipers with an accuracy of $0.01 \mathrm{~mm}$. Gross weight measurements were carried out using analytical scales. And, data collection on fishing ground is done by interviewing fishermen directly to find out the name of the location and the grid code based on the base map provided (Figure 2).

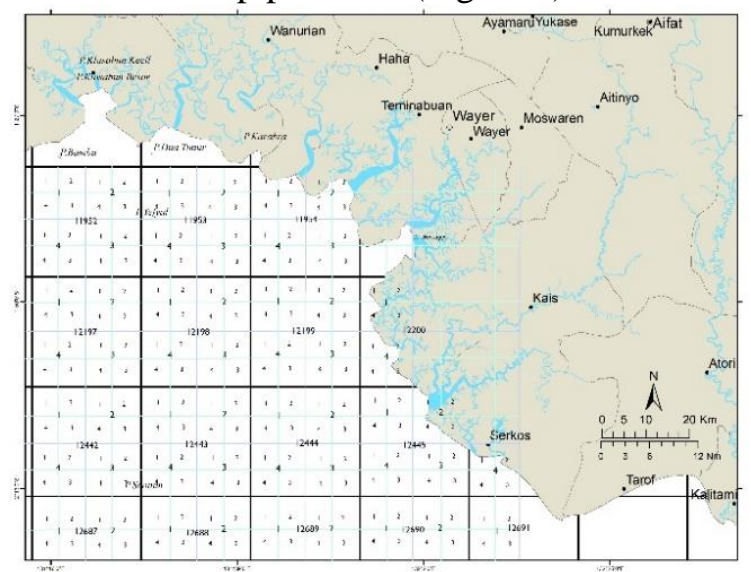

Figure 2. South Sorong Waters grid code

The results of carapace length sampling then grouped according to the fishing ground area of the fishermen in the designed marine protected area of South Sorong waters. The fishing ground in the No Take Zone can be seen in Table 1.

Table 1. Fishing Ground included in The Core Zone

\begin{tabular}{lll}
\hline $\begin{array}{l}\text { Data Collection } \\
\text { Location }\end{array}$ & Fishing Area & Zone \\
\hline Kais & Tanjung Jarum & NTZ2 \\
\hline Seremuk & Seremuk & NTZ2 \\
\hline Konda & Seneboy & NTZ2 \\
\hline Inanwatan & Muara sigei & NTZ3 \\
\hline Inanwatan & Kali Siganoi & NTZ3 \\
\hline Inanwatan & Kali Sebora & NTZ3 \\
\hline Inanwatan & Laut Sebora & NTZ3 \\
\hline Inanwatan & Laut Isogo & NTZ3 \\
\hline
\end{tabular}

Determination of gonad maturity stage and sex of banana prawn was done by morphological observation referring to Dineshbabu (2013), which divides into five stages as follows: 


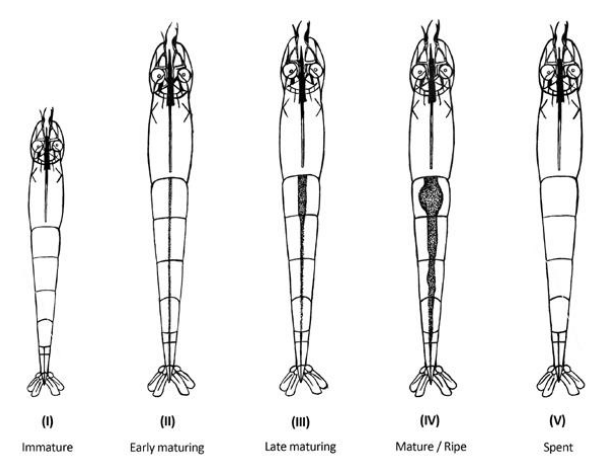

Figure 3. Different Gonad Maturity Stages in Prawn (Dineshbabu, 2013)

\section{Data Analysis}

\section{1) Distribution of Carapace Length}

Analysis of distribution of carapace length includes maximum length, minimum length, the average length of banana prawn, and length that often appears (modulus). Banana prawn length is expressed in carapace length with a class interval of $2 \mathrm{~mm}$ and is presented in the form of a histogram.

\section{2) Sex ratio}

The sex ratio was calculated by comparing the number of male banana prawn with the number of female banana prawn. The chi-square test was used to find out the relationship between male and female of banana prawn in the population. (Steel \& Torrie, 1993).

$$
X 2=\sum\left[(F o-F h)^{2} / F h\right](1)
$$

Notes:

$\mathrm{X} 2=$ The value for the random variable that is

chi

drawn, for example, approaches the square distribution

Fo $=$ Number of observed male and female frequencies (Ind)

$\mathrm{Fh}=$ Number of observed male and female frequencies (Ind)

\section{3) Length-Weight Relationship}

Analysis of length-weight data with the allometric linear model (LAM) was used to calculate parameters $a$ and $b$ through measurements of changes in weight and length. The bias correction on the change in the average weight of the logarithmic unit was used to predict the weight of the length parameter according to the following allometric equation, based on DeRobertis \& William (2008).

$$
W=a L^{b}
$$

Notes:

$\mathrm{W}=$ Prawn weight $(\mathrm{gr})$

$\mathrm{L} \quad=$ Carapace length of banana prawn (mm)

$a$ and $b=$ Constants

\section{4) Condition Factor}

The relative weight (Ar) and the coefficient $(\mathrm{K})$ of the condition factors were used to evaluate the condition factors of each individual. The relative weight (Wr) was determined based on equation [5].

$$
W r=\left(\frac{W}{W s} \times 100\right)
$$

Notes:

$\mathrm{Wr}=$ Relative weight

$\mathrm{W}=$ Individual weight

$\mathrm{Ws}=$ The predicted standard weight from the Same sample

Ws was calculated from the combined length-weight regression through distances between species:

$$
W a=a L^{b}
$$

The condition factor was estimated using the King (1995) equation in [6].

$$
K t=10^{2} \mathrm{~W} / L^{3}
$$

Notes:

$\mathrm{Kt}=$ Condition factor

$\mathrm{W}=$ Weight $(\mathrm{g})$,

$\mathrm{L}=$ Length $(\mathrm{mm})$

\section{5) Length at First Capture (Lc) and Length at} First Maturity ( Lm)

The average length at the first capture (Lc) was calculated by the method of the layered bag or covered contents method [7]. The results of these calculations formed an active selectivity curve in a sigmoid-shaped device that resembles a cumulative normal distribution curve. This condition was suspected through the Beverton and Holt method as presented in [8].

$$
S L=\frac{1}{1+\exp (\mathrm{a}-\mathrm{b} \times \mathrm{L})}
$$

Notes:

$\mathrm{SL}=$ Estimated value of length

$\mathrm{L}=$ Middle value of length class $(\mathrm{mm})$

$a$ and $b$ are constants, so that $a$ and $b$ can be calculated by assuming linear regression: 


$$
\ln \left(\frac{1}{\mathrm{SL}_{\mathrm{c}}}-1\right)=\mathrm{a}-\mathrm{b} \times \mathrm{L}
$$

Notes:

$\mathrm{SL}_{\mathrm{c}}=$ Relative cumulative frequency

$\mathrm{L}=$ Middle value of length class $(\mathrm{mm})$

Lc was calculated with:

$$
L c=-\frac{\mathrm{a}}{\mathrm{b}}
$$

Estimation of the length at first maturity using the Spearman-Karber method (Undupa, 1986).

$$
m=\left[\mathrm{xk}+\left(\frac{\mathrm{x}}{2}\right)\right]-\left(\mathrm{x} \sum \mathrm{pi}\right)
$$

$\mathrm{Lm}=$ Antilog $\mathrm{m}$ with 95\% confidence interval for $\log \mathrm{m}$ which is limited as follows:

$$
\mathrm{Lm}=\operatorname{antilog} \mathrm{m}=\mathrm{m} \pm 1,96 \sqrt{X^{2} \sum \frac{p i q i}{n i-1}}
$$

Notes:

$\mathrm{m}=$ Log of carapace length on first gonad maturity

$\mathrm{xk}=\log$ of the middle class of length class with the largest proportion of mature

$\mathrm{x}=$ Log of length increase in the middle value, $p i$ is the proportion of mature

in the $\mathrm{i}$-th class with the number of banana prawn in the i-th length interval

ni $=$ The number of banana prawns in the $\mathrm{i}$ length class, $q i$ is 1-pi.

\section{RESULT AND DISCUSSION}

\section{Distribution of Karapas Length}

One important information in the assessment of a fish population was the size structure [9]. The results of the analysis of the structure size of carapace length showed that the banana prawn caught in NTZ 2 had a larger size than the catch in NTZ 3, with the largest modus at $32 \mathrm{~mm}$ and $30 \mathrm{~mm}$ respectively. The frequency distribution of banana prawn carapace length based on NTZ presented as follows:

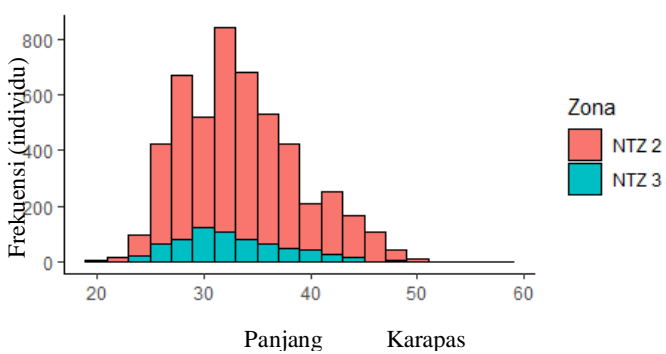

Figure 4. Length Frequency Distribution of Sampling Results Based on NTZ

Based on the analysis of the length of carapace maxium length found in NTZ 2 and NTZ 3 respectively with an average carapace length of $33.65 \pm 5.51 \mathrm{~mm}$ and $32.74 \pm 5.31$ $\mathrm{mm}$. This value showed that banana prawn size in the NTZ 3 zone was relatively smaller. Carapace length modus results obtained in South Sorong were still greater than obtained in the waters of North Central Java in AprilAugust by $28 \mathrm{~mm}$ [6].

The results of the analysis of the length composition of banana prawn based on NTZ showed that banana prawn fishing activities were mostly carried out in the NTZ zone 2, which indicated by a large number of samples identified in the zone (Figure 4).

Higher utilization activities in NTZ 2 happened due to this zone provide more optimal results. This caused by different environmental and ecosystem conditions in these two zones. NTZ 2 water area has more depth than NTZ 3. Other differences were mangrove species that dominate between the two zones, and river mouths were more commonly found in NTZ 2. The depth of water greatly influences the migration and reproduction patterns of adult banana prawn [10]. Adult-sized banana prawn were often found in waters that have a depth of more than 12 meters [10].

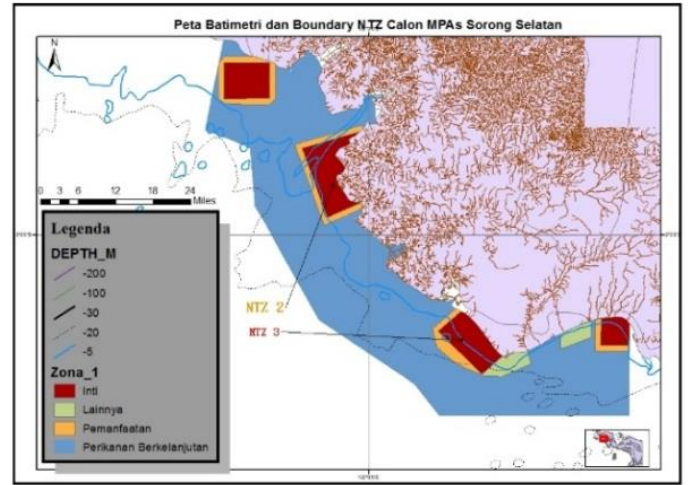

Figure 5. Map of Prospective NTZ and Bathymetry in The Sorong Selatan Marine Protected Area 
Based on Figure 5, the depth of the fishermen's fishing ground in NTZ 2 ranges between 5-10 meters and in NTZ 3 ranges between 5-10 meters and 20-30 meters. Banana prawn could be found to a depth of 55 meters [11]. Meanwhile, Pramonowibowo et al. (2007) state that the deeper the waters, the size of the white prawn obtained also tends to be even greater. According to Feat (1992) that the prawn spawned in the offshore zone to a depth of 100 and headed estuary for enlargement. According to [12], the pattern of the relationship between inland with the catch of banana prawn in Kaimana-Timika waters follows a quadratic regression equation model that shows that the production of catches is in the form of a parabola that has a point. At depths $<17$ meters, catches tend to increase, while at depths $>17$ meters, catches tend to decrease. If based on this, then NTZ 2 provides optimal catch production for prawn fishing activities.

\section{Sex Ratio}

Prawn sex ratio results in South Sorong waters between NTZ 2 and NTZ 3 showed that male banana prawn was found less than female prawn in both zones with a total ratio of 0.49:1 between males and female. The same thing was also found in Estaraari Segara Anakan Cilacap which shows a male: female ratio of 1:1.24 [13]. However, a different matter was found by [10] in the Percut Sei Tuan North Sumatra mangrove forest area which found a higher sex proportion of male banana prawn of 1.007. According [14], the ratio of male and female genitalia in nature has estimated to be close to 1: 1, thus showing that the number of captured males and females will be proportional.

Table 2. Sex ratio of banana prawn in South Sorong by NTZ

\begin{tabular}{llllll}
\hline \multirow{2}{*}{ NTZ } & \multicolumn{2}{c}{ Gender Ration } & \multicolumn{3}{c}{ Individual Number } \\
\cline { 2 - 6 } & Male & Female & $\begin{array}{l}\text { Number } \\
\text { of Male }\end{array}$ & $\begin{array}{l}\text { Number of } \\
\text { Female }\end{array}$ & Total \\
\hline 2 & 0,28 & 1 & 874 & 3077 & 3951 \\
3 & 0,20 & 1 & 108 & 530 & 638 \\
Total & 0,49 & 1 & 982 & 3607 & 4589 \\
\hline
\end{tabular}

The results of the sex ratio analysis showed a calculated Chi-Square value of 31.76 more than the Chi-Square Table value of 11.07 , so it can be stated that there was an imbalance of male and female populations in the two zones. This was reinforced by the pvalue (probability value) Chi-Square 0.003 $<0.05$. The gender ratio in aquatic biota was important to know to see the stability of the banana prawn population in nature. According to [15], differences in sex ratio can be caused by biological differences between the sexes of males and females both in terms of size or phase/life cycle of banana prawn. Meanwhile, according to [16], the difference in ratio between the number of males and females can be due to differences in growth rates between sexes, mortality, and migration zones differ between sexes.

\section{Length at First Capture (Lc) and Length at First Maturity (Lm)}

The result showed that there were differences in the values of $\mathrm{Lc}$ and $\mathrm{Lm}$ in the two NTZs. The length at first capture of banana prawn caught (Lc) obtained in NTZ 2 was $34.64 \mathrm{~mm}$ and NTZ 3 was $34.04 \mathrm{~mm}$. The length at first maturity of banana prawns (Lm) in NTZ 2 was $35.77 \mathrm{~mm}$, while in NTZ 3 was $33.65 \mathrm{~mm}$. If we look at the comparison between Lc and Lm values in the two zones, the size captured in NTZ 2 was still below the mature gonad size or Lc < Lm (Figure 6). Ideally, the banana prawn that have been caught are above the length of the carapace's first mature gonads (Lm).

Observations in Sampit waters conducted by Nurdin \& Kembaren (2015) showed that banana prawn caught was dominated by relatively young banana prawn, which was at a carapace length of $32 \mathrm{~mm}$ and had the size of the first time caught was also smaller than the average length First time mature gonads $(\mathrm{Lc}<\mathrm{Lm})$.

Meanwhile, observations made by [17] in the northern waters of Central Java also showed $\mathrm{Lc}<\mathrm{Lm}$ results with a value of $\mathrm{Lc}$ $29.40 \mathrm{~mm}$, smaller than the results of this study, and $\mathrm{Lm} 42.55 \mathrm{~mm}$, greater than the results of the study this. If this left unchecked, result in banana prawn stocks that could decline in these locations. This also cut the prawn opportunity to reach adulthood (recruitment overfishing), especially in the location of water conservation areas. Lc value which was smaller than the Lm value in NTZ 2 was presumably due to the greater utilization activity in the location. However, the size of banana prawn obtained in NTZ 2 
was relatively larger than NTZ 3. This can be used as a reference to immediately make a management step so that the size of the larger banana prawn does not shrink.

If the values of length at first capture can be maintained above the value of the length at first maturity $(\mathrm{Lm})$, the yield per recruit will be stable. According to [18], the use of resources that have not yet taken the opportunity to reproduce will threaten the population of these resources. By comparing the values of $\mathrm{Lc}$ and $\mathrm{Lm}$, we can get an idea of the estimated sustainability of the population stock. However, a population stock will survive if the average fish caught was larger than the length when the gonad (Lm) was first mature [19].

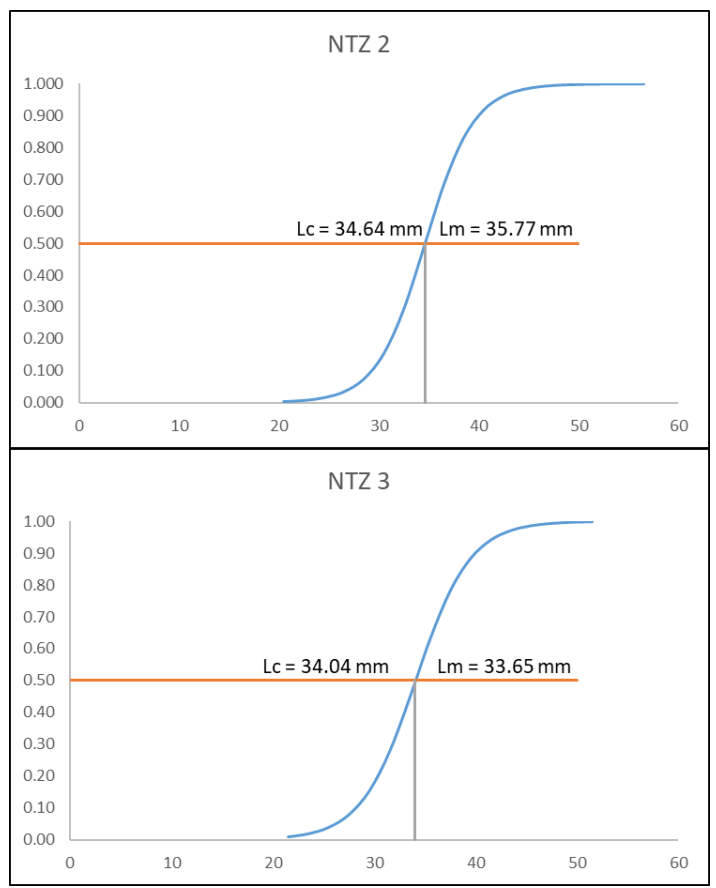

Figure 6. Logistic Curves of Catches in Each Zone Showing Lc Value Compared with Results of Lm Value Analysis

\section{Length-Weight Relationship and Condition Factors}

The number of banana prawn measured by length and weight was 3,894 individuals in NTZ 2 and 639 individuals in NTZ 3, with an average weight of individual banana prawn of $35.80 \pm 0.22$ and $33.18 \pm 0.55$, respectively. The relative weight of banana prawn $(\mathrm{Wr})$ based on the results of the analysis was $101.05 \pm 3.51 \mathrm{gr}$ on NTZ 2 and $101.53 \pm 12.05$ gr. The results of the length-weight analysis show that both locations have $b$ values smaller than 3 (b < 3), respectively in NTZ 2 and NTZ
3 of 2.0587 and 2.2246, which means that growth is negative allometric type. Growth patterns in aquatic biota are divided into two types, namely isometric growth $(b=3)$. The length and weight gain of banana prawn were balanced and allometric growth, the value was $\mathrm{b}>3$ or $\mathrm{b}<3$. If the value was $\mathrm{b}>3$, this shows that the banana prawn was fat/plump, where the weight gain is faster than the length increase. Whereas, if $b<3$ on the results of the analysis, this shows the condition where the banana prawn were in the category of length increase faster than their body weight [20].

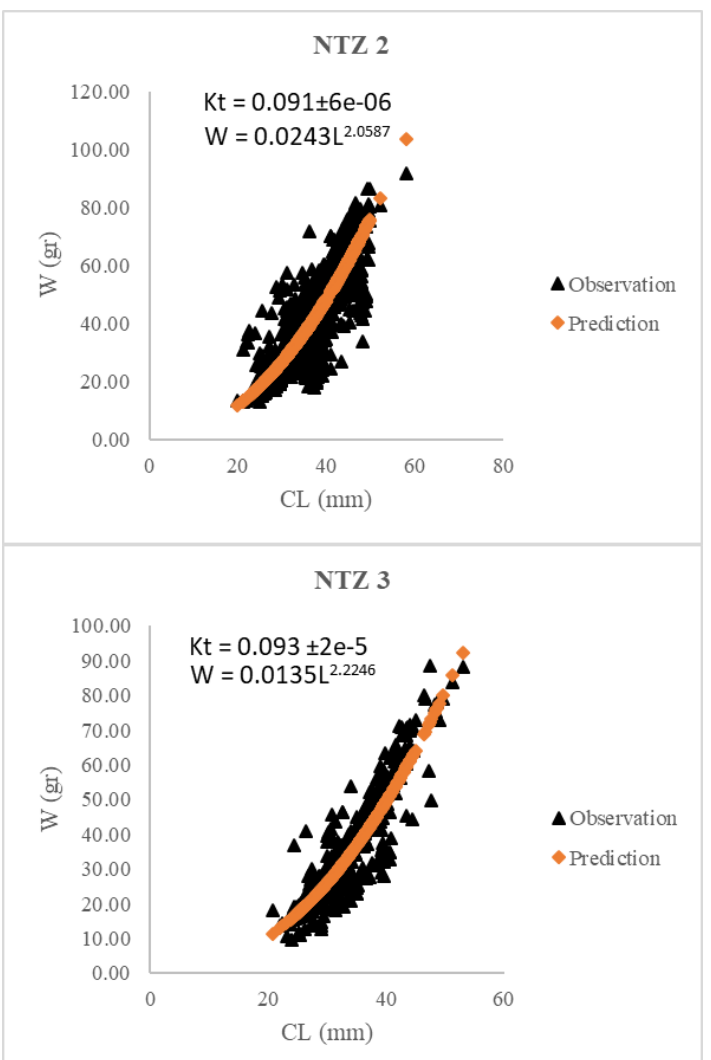

Gambar 7. Length-Weight Relationship and Condition Factor of Banana Prawn in Sorong Selatan Marine Protected Area

[21] suggest that body weight in fish (prawn) will approximately equal to body volume in $\mathrm{cm}^{3}$, and the volume arena is sometimes proportional to the cubic of its length, ideally $b$ will approach a value of 3 . Although the value $b$ obtained is smaller than 3 , but when compared between the two locations, NTZ 3 has a relatively large coefficient $b$. The long-weight relationship of prawn was more stable than prawn caught by NTZ 2. [17] stated that the differences in the 
weight of banana prawn in the waters were thought to be caused by changes in food availability in nature and environmental factors, which closely related to the condition of the substrate waters.

The average condition factors in NTZ 2 and NTZ 3 were respectively $0.091 \pm 6 \mathrm{e}-06$ and $0.093 \pm 2 \mathrm{e}-05$. These results indicated that the value follows the results of the coefficient $b$ of the linear equation of the length-weight relationship. The results of the condition factors at the two locations were relatively the same even though when viewed from the nominal NTZ 3 has better environmental conditions. Besides, being influenced by the environment, the condition factor was also influenced by physiological conditions, especially the reproductive activity of prawn. [22] stated that the value of the condition factors obtained will tend to produce high values following the level of gonadal observations due to the relationship between gonad maturity and overall body weight gain.

From the analysis results, the observed weight (observation weight $/ \mathrm{W}$ ) and the predicted weight (prediction weight / Ws) at both locations showed relatively similar results, where the observed weight was still in the same pattern with the predicted prediction value. This illustrates that both locations had optimum growth conditions and the aquatic environment provides optimum food to support the growth of banana prawn.

\section{CONCLUSION}

The conclusions obtained from this study are:

- Analysis of sex ratio in both zones shows that female banana prawn populations dominate in both zones.

- Banana prawn population conditions in NTZ 3 were relatively more stable than NTZ 2 based on the analysis of the relationship of length-weight, condition factors, and the ratio of the length at first capture $(\mathrm{Lc})$ to the length at first maturity (Lm).

To maintain the availability of healthy population stock, it was necessary to manage one of them is the initiation of MPA (marine protected area) which was supported by zonebased management, namely the application of the core zone which is partly a reservoir of banana prawn resources for the community. Determination of part of the NTZ 3 zone as a no-take zone was considered most appropriate if you see that the size of the banana prawn in the area was smaller than NTZ 2. Besides, resource utilization in NTZ 3 was lower. Based on the conclusions above, several things are recommended including:

- The fishing ground in NTZ 2 needs to be shifted to another fishing area so that the optimization of the no-take zone can serve to maintain reproductive stability to support sustainable and sustainable fisheries.

- In NTZ 3, management is recommended with two aspects, which are utilization, and protection. NTZ 3 can encourage using the open-close season or sasi strategy. While, the strategy of catching time to optimize size to increase banana prawn production by considering protection, preservation, and utilization.

- In both NTZs, banana prawn are caught below the optimum size. If the banana prawn that are caught are the optimum size of banana prawn, then the core zone or the selectivity setting of the fishing gear in the two zones needs to be done, especially in NTZ 2.

- A more in-depth study is needed regarding the size distribution of banana prawn populations within the MPA to ensure strategic locations for spawning and raising banana prawns. Also, the banana prawn abundance survey will strongly strengthen management recommendations that are appropriately related to the zoning of prospective MPA.

\section{ACKNOWLEDGE}

This research activities are fully supported by USAID through the Sustainable Ecosystem Advanced (SEA) Project. The researchers also said thank you to Oktavianto Prasetyo Darmono, Inayah, Muhammad Maskur Tamanyira, and Aomri Sihotang because they helped to monitor data collection activities for this study. 


\section{REFERENCES}

[1] USAID SEA, "Laporan Survey Data Dasar Sorong Selatan Provinsi Papua Barat. Ekologi, Perikanan, dan Status Sosial Masyarakat". USAID Sustainable Ecosystem Advanced (SEA) Project Indonesia. 2017.

[2] P. I. Farfante and B. Kensley, "Penaeoid and sergestoid prawns and prawns of the world. Keys and diagnoses for the families and genera," Bulletin of Marine Science, vol. 62, no. 1, page 299-301, Jan 1998.

[3] E. Kusrini, "Menggali Sumberdaya Genetik Udang Jerbung Sebagai Kandidat Udang Budidaya Di Indonesia," Akuakultur Media, vol. 6 , no. 1, hal. 49-53, 2011.

[4] D. A. Hedianto, S. E. Purnamaningtiyas, dan Riswanto, "Sebaran dan Habitat Juvenile Udang Penaeid di Perairan Kuburaya Kalimantan Barat," Jurnal Bawal, vol. 6, no. 2, hal. 77-88, August 2014.

[5] A. L. Rypel and T. J. Richter, "Emperical percentile standard weight equation for the Blacktail Redhorse," North American Journal of Fisheries Management, vol. 28, page 1843-1846, 2008.

[6] Tirtadanu dan T. Ernawati, "Kajian Biologi Udang Jerbung (Penaeus merguiensis) De Man". 1888) di Perairan Utara Jawa Tengah", Jurnal Bawal. Vol. 8, no. 2, hal. 109-116, Aug 2016.

[7] J. S. Hasibuan, M. Y. Boer, dan Y. Ernawati, "Struktur Populasu Ikan Kurau Polynemus dubius Di Teluk Pelabuhan Ratu," Journal of Tropical Marine Science and Technology, vol. 10, no. 2, hal. 441-453, August 2018.

[8] P. Sparre dan S. C. Venema, "Introduksi Pengkajian Stok Ikan Tropis Buku I Manual. Badan Penelitian dan Pengembangan Pertanian (penerjemah)," Cooperation of Food Organizations,
United Nations and Fisheries Research and Development Center. Jakarta, Page 57. 1999.

[9] M. C. Kamarullah, "Dinamika populasi dan biologi reproduksi ikan swanggi". (Priacanthus tayenus Richardson, 1846) (Studi Kasus Perairan Selat Sunda) Provinsi Banten," Thesis. Institut Pertanian Bogor, page. 77, Sep 2016.

[10] M. B. Mulya, "Kajian Bioekologi Udang Putih (Penaeus merguiensis de Man) di Ekosistem Mangrove Percut Sei Tuan Sumatera Utara," Desertasi. Institut Pertanian Bogor, Page 75-99. Jan 2012.

[11] Central Marine Fisheries Research Institute. Indian Council of Agricultural Research, India, 1988.

[12] M. A. Rozaki, A. Arfah, Rohyadi, F. Hoek, "Estimasi Sebaran Frekuensi Panjang Udang (Penaeus merguiensis) Yang Tertangkap Dengan Alat Tangkap Pukat Udang Di Perairan KaimanaTimika," Airaha Journal, vol. 3, no. 1, hal. 10-18, Jul 2014.

[13] S. W. Saputra, S. Sukimin, M. Boer, R. Affandi, dan D. R. Monintja, "Aspek Reproduksi dan Daerah Pemijahan Udang Jari (Metapenaeus elegans De Man, 1907) di Laguna Segara Anakan, Cilacap, Jawa Tengah. Jurnal Ilmu Kelautan, vol. 10, no. 1, hal. 41 - 49, Mar 2005.

[14] S. B. A. Omar, M. Nur, M. T. Umar, M. A. Dahlan, dan S. Kune, "Nisbah Kelamin dan Ukuran Pertama Kali Matang Gonad Ikan Endemik Pirik (Lagusia micracanthus Bleeker, 1860) Di Sungai Pattunuang, Kabupaten Maros, dan Sungai Sanrego, Kabupaten Bone, Sulawesi Selatan," Semnaskan UGM/Budidaya Perikanan, BP. 13, hal. 73-81, 2015.

[15] K. Wagiyo, A. Damora, A. R. P. Pane, "Aspek Biologi, Dinamika Populasi, dan Kepadatan Stok Udang Jerbung (Penaeus merguiensis De Man, 1888) Di Habitat Asuhan Estuaria Segara 
Anakan, Cilacap," Indonesian Fisheries Research Journal, vol. 24, no. 2, hal. 127-136, June 2018.

[16] S. M. Pillai, T. Rajyalakshmi, and P. Ravichandran, "Some Observations on The Biology and Fishery of the Banana prawn Penaeus merguiensis de Man," Journal of Marine Biology Association. India, vol. 33, no. 1 \& 2, page 409-417, 1991.

[17] Tirtadanu, Suprapto, dan A. Suman, "Sebaran Frekuensi Panjang, Hubungan Panjang-Berat, Tingkat Kematangan Gonad Dan Rata-Rata Ukuran Pertama Kali Matang Gonad Udang Putih (Penaeus merguiensis De Man”. 1888) di Perairan Kota Baru, Kalimantan Selatan. Jurnal Bawal. vol. 9, no. 3, hal. 145-152, Sep 2017.

[18] L. E. Miranda, A.A. Agostinho and L.C. Gomes, "Appraisal of The Selective Properties of Gill Nets and Implications for Yield and Value of The Fisheries at Tha Itaipu Reservoir, Brazil-Paraguay," J. Fish. Res, vol. 45, no. 2000, page 105-116, Sep 1999.
[19] Nurhayati, Fauziyah dan S. M. Bernas, "Hubungan Panjang-Berat Dan Pola Pertumbuhan Ikan Di Muara Sungai Musi Kabupaten Banyuasin Sumatera Selatan," Maspari Journal, vol. 8, no. 2, hal. 111-118, Jul 2016.

[20] Nurhayati, Fauziyah dan S. M. Bernas, "Hubungan Panjang-Berat Dan Pola Pertumbuhan Ikan Di Muara Sungai Musi Kabupaten Banyuasin Sumatera Selatan," Maspari Journal, vol. 8, no. 2, hal. 111-118, Jul 2016.

[21] P. Sparre and S. C. Venema, "Introduksi Pengkajian Stok Ikan Tropis Buku I Manual. Badan Penelitian dan Pengembangan Pertanian(penerjemah)". Cooperation of Food Organizations, United Nations and Fisheries Research and Development Center. Jakarta, page 438. 1999.

[22] Z. A. Muchlisin, A. Muhadjier, Zulkarnaini, S. Purnawan, S. H. Cheng, I. Setiawan, "Hubungan Panjang Berat Dan Faktor Kondisi Tiga Spesies Cumi Hasil Tangkapan Nelayan Di Perairan Laut Aceh Bagian Utara," BionaturaJournal of Life and Physical Sciences, vol. 16, no. 2, hal. 72-77, Jul 2014. 